\title{
QUALITY OF ACEROLA (Malpighia emarginata) TREATED WITH GIBBERELIC ACID AND STORED UNDER REFRIGERATION ${ }^{1}$
}

\author{
KELLINA OLIVEIRA DE SOUZA², CARLOS FARLEY HERBSTER MOURA ${ }^{3}$, \\ MÔNICA MARIA DE ALMEIDA LOPES ${ }^{4}$, MARCELA CRISTINA RABELO ${ }^{4}$, \\ MARIA RAQUEL ALCÂNTARA DE MIRANDA ${ }^{4}$
}

\begin{abstract}
The goal of this study was study the postharvest quality of acerola clone BRS 236 (Malpighia emarginata D.C.) which was harvested at physiological maturity and submitted to four treatments under immersion during 5 minutes at $25^{\circ} \mathrm{C}$, which are: control (water), $60 \mathrm{mg} \mathrm{L}^{-1} ; 120 \mathrm{mg} \mathrm{L}^{-1}$ and $180 \mathrm{mg} \mathrm{L}^{-1}$. After treatment the fruits were packed in polystyrene trays and placed with polyethylene film and then stored at $10 \pm 2{ }^{\circ} \mathrm{C}$ and $85 \pm 5 \% \mathrm{RH}$ for 12 days. Were analyzed in three days intervals ( $0,3,6,9$ and 12 days): skin color, firmness, $\mathrm{pH}$, titratable acidity, soluble solids, $\mathrm{SS} / \mathrm{TA}$ ratio, vitamin $\mathrm{C}$ and yellow flavonoids. Vitamin $\mathrm{C}$, anthocyanins and yellow flavonoids were not influenced by treatments with $\mathrm{GA}_{3}$ at the end of 12-day of cold storage at $10^{\circ} \mathrm{C}$. The exogenous application of $120 \mathrm{mg} \mathrm{L}^{-1}$ of GA 3 resulted in retention of red color and content of anthocyanins of acerola fruits BRS 236 clone 12-day storage at $10^{\circ} \mathrm{C}$.

Index Terms: Color; Storage; Firmness; Vitamin C; Gibberellin.

\section{QUALIDADE PÓS-COLHEITA DE ACEROLAS (Malpighia emarginata) TRATADAS COM ÁCIDO GIBERÉLICO E ARMAZENADAS SOB REFRIGERAÇÃO}

RESUMO- Objetivou-se com este trabalho estudar a qualidade pós-colheita de acerolas do clone BRS 236 (Malpighia emarginata D.C.), colhidas na maturidade fisiológica e submetidas a quatro tratamentos com ácido giberélico ( $\mathrm{GA}_{3}$ ) por imersão durante 5 minutos a $25^{\circ} \mathrm{C}$, sendo eles: controle (água), $60 \mathrm{mg} \mathrm{L}^{-1}$; $120 \mathrm{mg} \mathrm{L}^{-1} \mathrm{e} 180 \mathrm{mg} \mathrm{L}^{-1}$. Após o tratamento os frutos foram colocados em bandejas de isopor e cobertos com filme de polietileno, e em seguida armazenados à temperatura de $10 \pm 2{ }^{\circ} \mathrm{C}$, com umidade relativa de $85 \pm 5 \%$, durante 12 dias. Foram analisadas em intervalo de três dias (0, 3, 6, 9 e 12 dias): coloração da casca, firmeza, $\mathrm{pH}$, acidez total titulável, sólidos solúveis, relação SS/AT, vitamina C e flavonóides amarelos. Compostos bioativos como a vitamina $\mathrm{C}$ e flavonóides não foram influenciados pelos tratamentos com $\mathrm{GA}_{3}$ ao final de 12 dias de armazenamento a $10{ }^{\circ} \mathrm{C}$. A aplicação exógena de $120 \mathrm{mg} \mathrm{L}^{-1}$ de $\mathrm{GA}_{3}$ resultou em maior retenção da cor e conteúdo de antocianinas em acerolas do clone BRS 236 durante 12 dias de armazenamento a $10^{\circ} \mathrm{C}$. Termos para indexação: Cor; Armazenamento; Firmeza; Vitamina C; Giberelinas

\footnotetext{
1(Paper 017-16). Received on January 26, 2016. Accepted on March 16, 2016.

${ }^{2}$ Universidade Federal do Ceará, Departamento de Fitotecnia, Bloco 805, Av. Mister Hull, 2977, Campus do Pici, CEP: 60356-000, Fortaleza-CE, Brasil. E-mail: kellina@gmail.com

${ }^{3}$ Embrapa Agroindústria Tropical, Rua Dra Sara Mesquita, CEP 60511-110, Fortaleza-CE, Brasil. E-mail : farley.moura@embrapa.br ${ }^{4}$ Universidade Federal do Ceará, Departamento de Bioquímica e Biologia Molecular, Bloco 907, Mister Hull 2297, Campus do Pici, CEP 60451-970, Fortaleza-CE, Brasil; E-mail: monicalopes5@hotmail.com; marcelacrabelo@gmail.com; rmiranda@gmail.com
} 


\section{INTRODUCTION}

The fruit of the acerola tree (Malpighia emarginata DC) is known to be a rich source of vitamin $\mathrm{C}$ and has become popular as a functional food among the most health conscious consumers who prefer to obtain this vitamin from natural sources (AQUINO et al., 2011 1996). The selection of clones is the most efficient way to supply the immediate demand for genotypes with higher productivity and vitamin $\mathrm{C}$ content. The BRS 236 clone or also called "cherry" produced 49 tons of fruits per hectare with

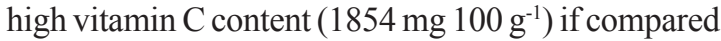
with other clones such as Florida Sweet (862 mg 100 $\mathrm{g}^{-1}$ ), Flor Branca (1104 mg $100 \mathrm{~g}^{-1}$ ) and BRS 366 (1363 mg $100 \mathrm{~g}^{-1}$ ) (SOUZA et al., 2014).

The acerola is a fruit with climacteric respiratory pattern, that which undergoes various transformations during the maturation, ripening and senescence processes (CHITARRA; CHITARRA, 2005), highlighting the degradation of chlorophyll, carotenoids synthesis and loss of vitamin C. In this way, the acerola has a short postharvest with losses of $40 \%$, due to their high respiratory rate and fragile structure, being necessary the use of processing techniques capable to prolong the conservation of the fruits, extending the postharvest (MATSUURA, 2001). The effect of regulators such as $\mathrm{GA}_{3}$ (50 and $100 \mathrm{mg} \mathrm{L}^{-1}$ ) and benzylaminopurine (50 and 100 $\left.\mathrm{mg} \mathrm{L}^{-1}\right)$ on acerola at the unripe stage had no effect on increase of storage period at refrigeration, and according to the authors, only the refrigeration was sufficient to conserve the fruits during a period of 14 days (ANTUNES et al., 2006). Thus, alternatives technologies such as modified atmospheres, refrigeration, as well as the exogenous application of phytohormones have been used to extend the postharvest of acerola.

The role of phytohormones such as auxins, gibberellins and cytokinins in fruit ripening is to act as retarders of senescence, while ethylene and abscisic acid are considered as fruit ripening promoters. The gibberellins affect changes on color of fruits, since they delay the loss of chlorophyll and consequently promote the accumulation of carotenoids (CHITARRA; CHITARRA, 2005). The application of plant hormones on fruit production has shown positive results in relation to the increase of the physical variables on pitayia (NOR et al., 2014), inhibition of maturation and extension of the postharvest of bananas (HUANG; JING, 2012), and improving of physiochemical characteristics of apples (YILDIZ et al., 2012). Among the plant regulators used in postharvest of fruits, gibberellic acid $\left(\mathrm{GA}_{3}\right)$ exerts a great influence on the quality and extension of postharvest of grapes (MARZOUK; KASSEM, 2011) and fruiting of atemoieira (PEREIRA et al., 2014).

The objective of this study was analyze the effects of exogenous $\mathrm{GA}_{3}$ on the physical, chemical and bioactive compounds of acerola fruit from acerola clone BRS 236 stored during a period of 12 days under refrigeration at $10{ }^{\circ} \mathrm{C}$.

\section{MATERIAL AND METHODS}

\section{Plant material and treatments}

Acerola from clone BRS 236 were manually harvested at Embrapa Agroindustria Tropical Station (latitude $4^{\circ} 11$ '26.62''S, longitude 38 $29^{\circ}$ '50.78' W) in the early hours of day. The fruits were selected for visual defects and uniformity and then submitted to the following treatments under immersion for $5 \mathrm{~min}$ at $25^{\circ} \mathrm{C}$ : (Control-without $\mathrm{GA}_{3}$ (water), -A), $(60 \mathrm{mg}$ $\mathrm{L}^{-1}$ of $\left.\mathrm{GA}_{3},-\mathbf{B}\right),\left(120 \mathrm{mg} \mathrm{L}^{-1}\right.$ of $\left.\mathrm{GA}_{3},-\mathbf{C}\right)$ and $(180$ $\mathrm{mg} \mathrm{L}^{-1}$ of $\mathrm{GA}_{3},-$ D). After treatments, the fruits were air dried, divided into three polystyrene trays with 15 fruits each and covered with PVC film $(0.03 \mathrm{~mm}$ thick). Then, the fruits were stored in a cold room at $10 \pm 2{ }^{\circ} \mathrm{C}$ and $85 \pm 5 \%$ relative humidity (RH) and were evaluated immediately after harvest and at each three day interval $(3,6,9$ and 12 days) for: color peel, firmness, $\mathrm{pH}$, titratable total acidity, soluble solids, SS/AT ratio, vitamin $\mathrm{C}$, total anthocyanins and yellow flavonoids.

\section{Physicochemical variables}

The color of fruits were measured using a portable colorimeter model CR-400 (Konica Minolta ${ }^{\circledR}$, Japan) which reported the values as $\mathrm{L}^{*}$ (luminosity), $\mathrm{a}^{*}$ (color change from green to red) and $b^{*}$ (color change from blue to yellow), through two readings performed at points equidistant from the fruits. Firmness was performed using a MagnessTaylor manual penetrometer (Model FT-02), with 2.0 $\mathrm{mm}$ diameter tips. Two readings were made per fruit on opposite sides, and the results were expressed in Newton. Soluble solids were determined according to the methodology recommended by AOAC (2005) using a digital refractometer model Atago ${ }^{\circledR N} 1$ (Kirkland-USA) with automatic temperature compensation, with results expressed in ${ }^{\circ} \mathrm{Brix}$. The acidity was determined by titration, according to AOAC (2005) using an automatic titrator (MettlerToledo ${ }^{\circledR}$ DL12, Columbus-USA) and the results expressed as percentage of (\%) malic acid. The SS/ AT ratio was obtained by ratio between the values 
of soluble solids and titratable acidity.

\section{Bioactive compounds}

Total vitamin $\mathrm{C}$ was determined according to Strohecker and Henning (1967) through of titration with Tillman's solution (2.6-dichlorophenolindophenol- $0.02 \%$, Sigma $\left.{ }^{\circledR}\right)$. One gram of pulp was diluted in $100 \mathrm{~mL}$ of oxalic acid $0.5 \%(\mathrm{v} / \mathrm{v})$ and homogenized. Then, $5 \mathrm{~mL}$ of this solution was diluted to $50 \mathrm{~mL}$ of distilled water and titrated with Tillman's solution, and results were expressed as $\mathrm{mg}$ $100 \mathrm{~g}^{-1}$ of fresh weight (FW).

Anthocyanins and yellow flavonoids were extracted and measured as described by Francis (1982). One gram of pulp was extracted with a $95 \%$ ethanol/1.5 N HCl (85:15) solution, vortexed for 2 min in a ultraturrax (IKA $\AA$, model Turrax T25, Germany) and then, the mixture was transferred to an amber flask which remained for 13 hours at $4{ }^{\circ} \mathrm{C}$. The mixture was filtered on Whatman N.1 paper, and the absorbance of the filtrate was measured at $535 \mathrm{~nm}$ for total anthocyanin content using an absorption coefficient of $98.2 \mathrm{~mol} \mathrm{~cm}^{-1}$, and at $374 \mathrm{~nm}$ for the yellow flavonoid content using an absorption coefficient of $76.6 \mathrm{~mol} \mathrm{~cm}^{-1}$. Both results were expressed in $\mathrm{mg} 100 \mathrm{~g}^{-1} \mathrm{FW}$.

\section{Statistical analysis}

The experiment used a design completely randomized with 5 refrigerated storage times $(0,3$, 6,9 and 12 days) and 4 doses of $\mathrm{GA}_{3}(0,60,120$ and $180 \mathrm{mg} \mathrm{L}^{-1}$ ), and each treatment was composed of three replicates. Data were submitted to analysis of variance (ANOVA), using ASSISTAT 7.6 software, through regression analysis, checking the coefficient of determination $\left(\mathrm{R}^{2}\right)$ at a level of $5 \%$ of significance.

\section{RESULTS AND DISCUSSION}

Physicochemical attributes

Color is a critical parameter and is directly linked to pigment concentration, which in the case of acerola is predominantly due to anthocyanins. The luminosity $\left(\mathrm{L}^{*}\right)$ represents the brightness on the fruit surface and did not differ between the different treatments $(\mathrm{p} \geq 0.05)$ evaluated, and were observed maximum values of luminosity on the 3rd day, followed by decrease until the end of the storage (Figure 1A). This behavior is possibly due to the changes on maturation stage of the fruits and initiation of the pigment synthesis. The $\mathrm{a}^{*}$ index (Figure 1B), represents a change of color from green to red, and the treated fruits presented a significant increase when compared to untreated, but application of $180 \mathrm{mg} \mathrm{L}^{-1}$ resulted in less red color intense from the 9 th day. The fruits treated with 120 $\mathrm{mg} \mathrm{L}^{-1}$ showed a more intense red coloration at end of storage ( 12 days) reaching an a* value two times higher (16.23) than the fruits that were treated with the highest dose of $\mathrm{GA}_{3}$ (8.12). The $b^{*}$ index (Figure $1 \mathrm{C})$, indicate the change of color from blue to yellow, and presented an increase in the 9th day of storage on acerola sprayed with $180 \mathrm{mg} \mathrm{L}^{-1}$, resulting in fruits with an intense yellow color compared to the other treatments. However, at the end of storage, no significant differences were observed between the different treatments. Antunes et al. (2006) observed that unripe acerola $\mathrm{GA}_{3}$-treated at concentrations of $50 \mathrm{mg} \mathrm{L}^{-1}$ and $100 \mathrm{mg} \mathrm{L}^{-1}$ stored under refrigeration remained the same color during 14 days. Already, Oliveira et al. (2012) evaluated the fruit development of five acerola clones concluded that with the advance of maturation, a decrease in luminosity of the fruits was observed.

In addition to the color, fruit firmness is one of the most important variables in quality, since it is inherent to the postharvest shelf life and fruit acceptability (OZTURK et al., 2012). Firmness represents one of the most important physical characteristics, since fruits with high firmness suggest have a longer postharvest. This characteristic is associated not only with the composition and structure of cell walls, but also with the maintenance of its integrity (CHITARRA; CHITARRA, 2005). A decrease on firmness was observed during refrigerated storage (Figure 2), without significant differences between the control and $\mathrm{GA}_{3}$-treated fruits. The fruits treated with 60 and $180 \mathrm{mg} \mathrm{L}^{-1}$ of $\mathrm{GA}_{3}$ presented higher values of firmness, reaching 3.07 and $3.78 \mathrm{~N}$ respectively, however, without significant differences between the treatments on the 12th day of storage. Retention of firmness is a key on refrigerated storage and in acerola is directly related to the maturation stage. Krishna et al. (2012) demonstrated that firmness of "Oregon Spur" apples was maintained during refrigerated storage using growth regulators such as AVG $\left(30 \mathrm{mg} \mathrm{L}^{-1}\right)$ and salicylic acid $\left(400 \mathrm{mg} \mathrm{L}^{-1}\right)$ during application in pre and postharvest.

The soluble solids content (SS) (Figure 3A) of treated fruits with $120 \mathrm{mg} \mathrm{L}^{-1}$ showed a significant increase compared to untreated fruits until the 6 th day of storage $\left(6.8^{\circ} \mathrm{Brix}\right)$. Fruits treated with $120 \mathrm{mg}$ $\mathrm{L}^{-1}$ and $180 \mathrm{mg} \mathrm{L}^{-1}$ of $\mathrm{GA}_{3}$ did not show significant differences throughout the refrigerated storage. The fruits treated with $60 \mathrm{mg} \mathrm{L}^{-1}$ presented the highest SS content $\left(8.2^{\circ} \mathrm{Brix}\right)$ at the end of the refrigerated storage. The titratable acidity (AT) (Figure $3 \mathrm{~B}$ ) 
increased until the 6th day of storage, reaching a maximum value of $2.11 \%$ for the fruits treated with $120 \mathrm{mg} \mathrm{L}^{-1}$ of $\mathrm{GA}_{3}$, without any difference between the control and the treatment with $60 \mathrm{mg} \mathrm{L}^{-1}$ of GA . However, at the end of the storage, a decrease in AT values was observed without significant difference between the control and the fruits $\mathrm{GA}_{3}$-treated. The decrease in acidity during ripening is explained by the use of organic acids as respiratory substrates or conversion to sugars, which may be associated with the increase in SS observed at the end of storage. Antunes et al. (2006) observed that treatments with $\mathrm{GA}_{3}\left(50 \mathrm{mg} \mathrm{L}^{-1}\right.$ and $100 \mathrm{mg} \mathrm{L}^{-1}$ ) in unripe acerola stored under refrigeration not influenced significantly the titratable acidity of the fruits. The SS/AT ratio is associated with fruit's taste, which in acerola is slightly acidic also evidenced by the low value observed (Figure 3C). The SS/AT ratio decreased until the 9th day of storage, followed by an increase at the end of storage, reaching a mean value of 5.13, without significant difference $(p \geq 0.05)$ between treatments. The fruits treated with $120 \mathrm{mg} \mathrm{L}^{-1}$ and $180 \mathrm{mg} \mathrm{L}^{-1}$ of $\mathrm{GA}_{3}$ presented higher values for the SS/AT ratio, and consequently resulted in sweeter acerola. Erogul and Sem (2015) evaluating the effect of gibberellic acid at concentrations of 50 and $75 \mathrm{mg}$ $\mathrm{L}^{-1}$ on plum quality (Prunus salicina Lindl.) related positive changes on color fruits and an increase in soluble solids content and firmness after application of $\mathrm{GA}_{3}$ was also observed.

\section{Bioactive compounds}

Total vitamin $\mathrm{C}$ is found in reduced (ascorbic acid) and oxidized (dehydroascorbate) forms which remain in a reversible equilibrium. The total vitamin $\mathrm{C}$ content decreased significantly from the 6th day of storage for all treatments (Figure 4A), being most pronounced in acerola treated with $120 \mathrm{mg} \mathrm{L}^{-1}$ of GA after 12 days of storage. However, the control did not differ statistically from the treated with $60 \mathrm{mg}$ $\mathrm{L}^{-1}$ of $\mathrm{GA}_{3}$. At the end of storage (12 days), the fruits still presented high vitamin C content (1724 mg 100 $\mathrm{g}^{-1} \mathrm{FW}$ ). Antunes et al. (2006) observed that unripe acerola treated with $\mathrm{GA}_{3}\left(50 \mathrm{mg} \mathrm{L}^{-1}\right.$ and $\left.100 \mathrm{mg} \mathrm{L}^{-1}\right)$ and stored under refrigeration did not have vitamin $\mathrm{C}$ content influenced by the exogenous application of $\mathrm{GA}_{3}$ during 14 days of storage.

Among the phenolics, anthocyanins are involved in important changes in the color of fruits and vegetables. In this study, it can be observed that the content of total anthocyanins increased during storage (Figure 4B). On the 12th day, the control and the fruits treated with $120 \mathrm{mg} \mathrm{L}^{-1}$ presented the highest content of total anthocyanins, reaching 6.80 and 6.31 mg. $100 \mathrm{~g}^{-1} \mathrm{FW}$ respectively, while the fruits treated with 160 and $180 \mathrm{mg} \mathrm{L}^{-1}$ of $\mathrm{GA}_{3}$ showed a reduction in the content of total anthocyanins, reaching 5.60

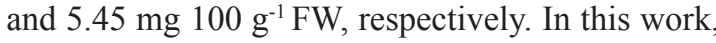
the application of $120 \mathrm{mg} \mathrm{L}^{-1}$ of $\mathrm{GA}_{3}$ is associated with an increase in the $\mathrm{a}^{*}$ values (Figure 1B) and accumulation of anthocyanins, which, according to Souza et al. (2014), make this compound the main polyphenol present in the ripe acerola. Miller and Rice-Evans (1997) reported that phenolics such as anthocyanins protect vitamin $\mathrm{C}$ from degradation. Conversely, Rosso and Mercadante (2007) suggested that anthocyanins can condense with ascorbic acid leading to a faster degradation of both compounds. Souza et al. (2014) evaluating anthocyanin content in acerola clones, observed that quercetin-3-ramnoside is the most abundant yellow flavonoid and that the content is dependent on the cultivar. In this study, yellow flavonoids significantly increased in amount during storage in association with the color change observed in fruits, however, no significant effect of $\mathrm{GA}_{3}$ was observed between treatments (Figure 4C). 

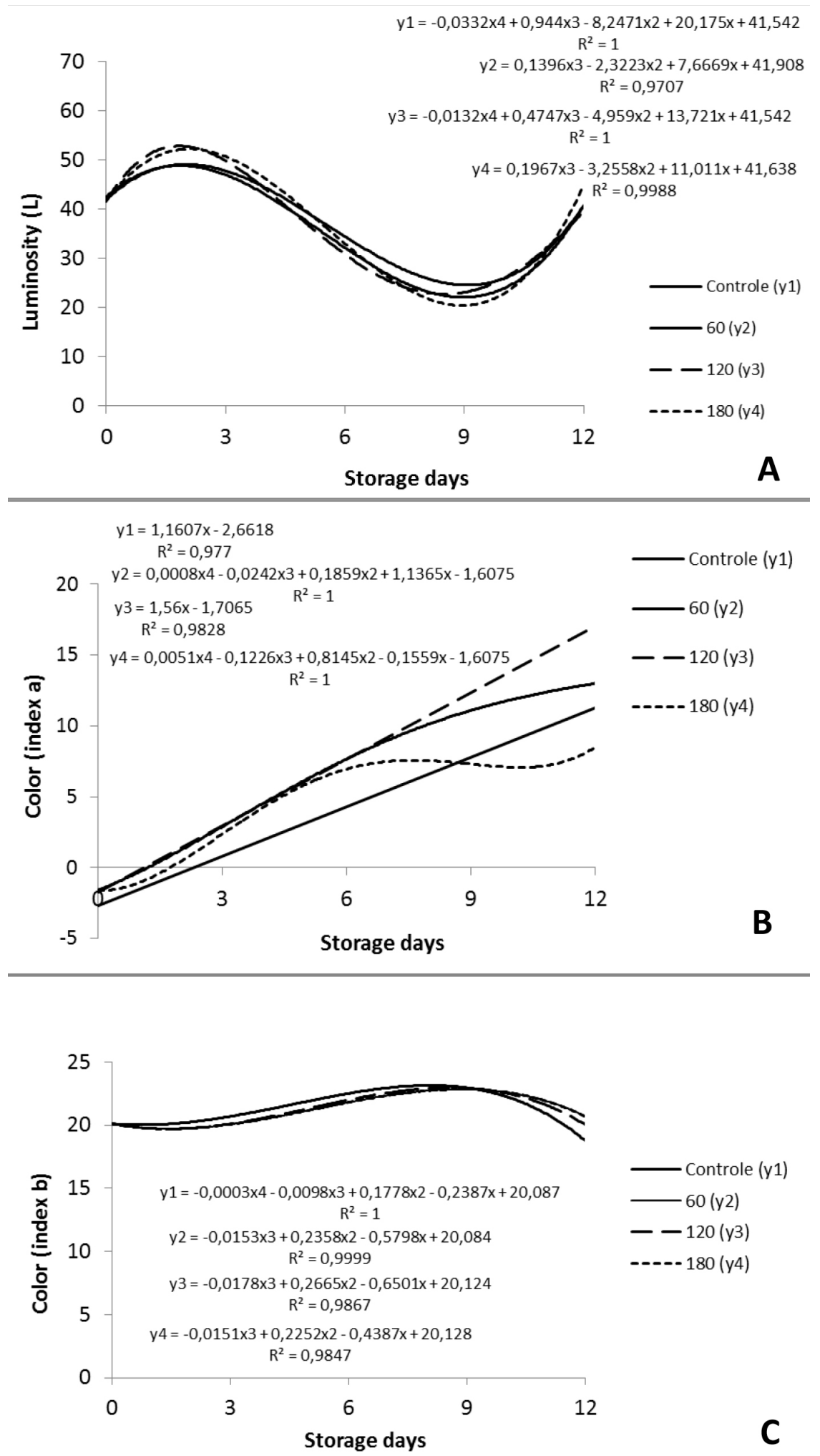

FIGURE 1- Changes on color of acerola from BRS 236 clone treated with different concentrations of de $\mathrm{GA}_{3}$ (A, Luminosity; $\mathbf{B}, \mathrm{a}^{*}$ value and $\mathbf{C}, \mathrm{b}^{*}$ value) during 12 days of storage at $10^{\circ} \mathrm{C}$. 


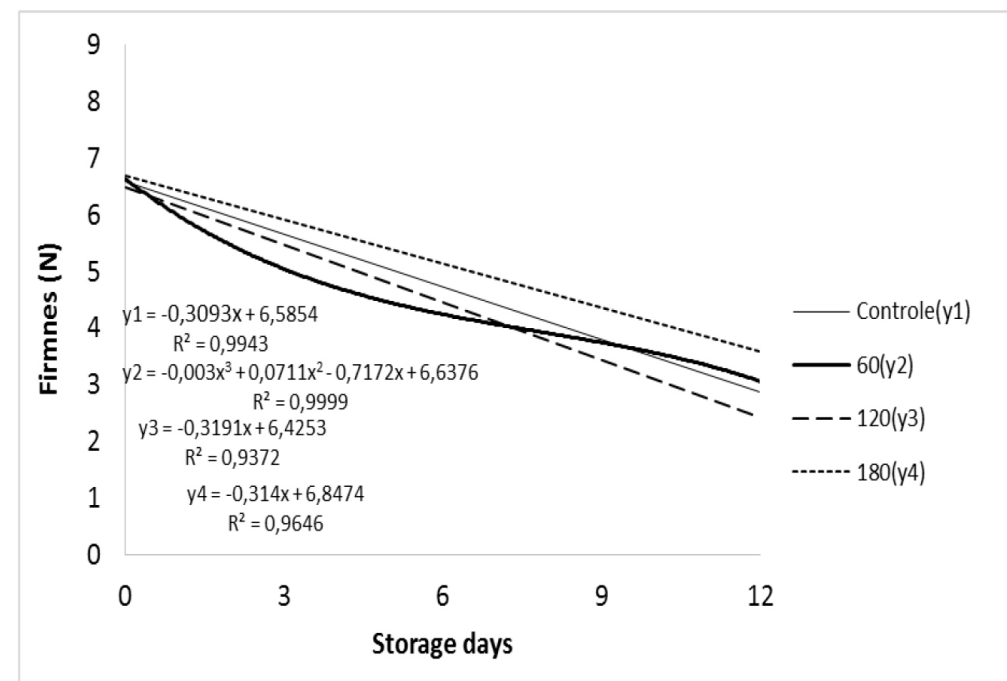

FIGURE 2-Changes on firmness of acerola from BRS 236 clone treated with different concentrations of de $\mathrm{GA}_{3}$ during 12 days of storage at $10{ }^{\circ} \mathrm{C}$.

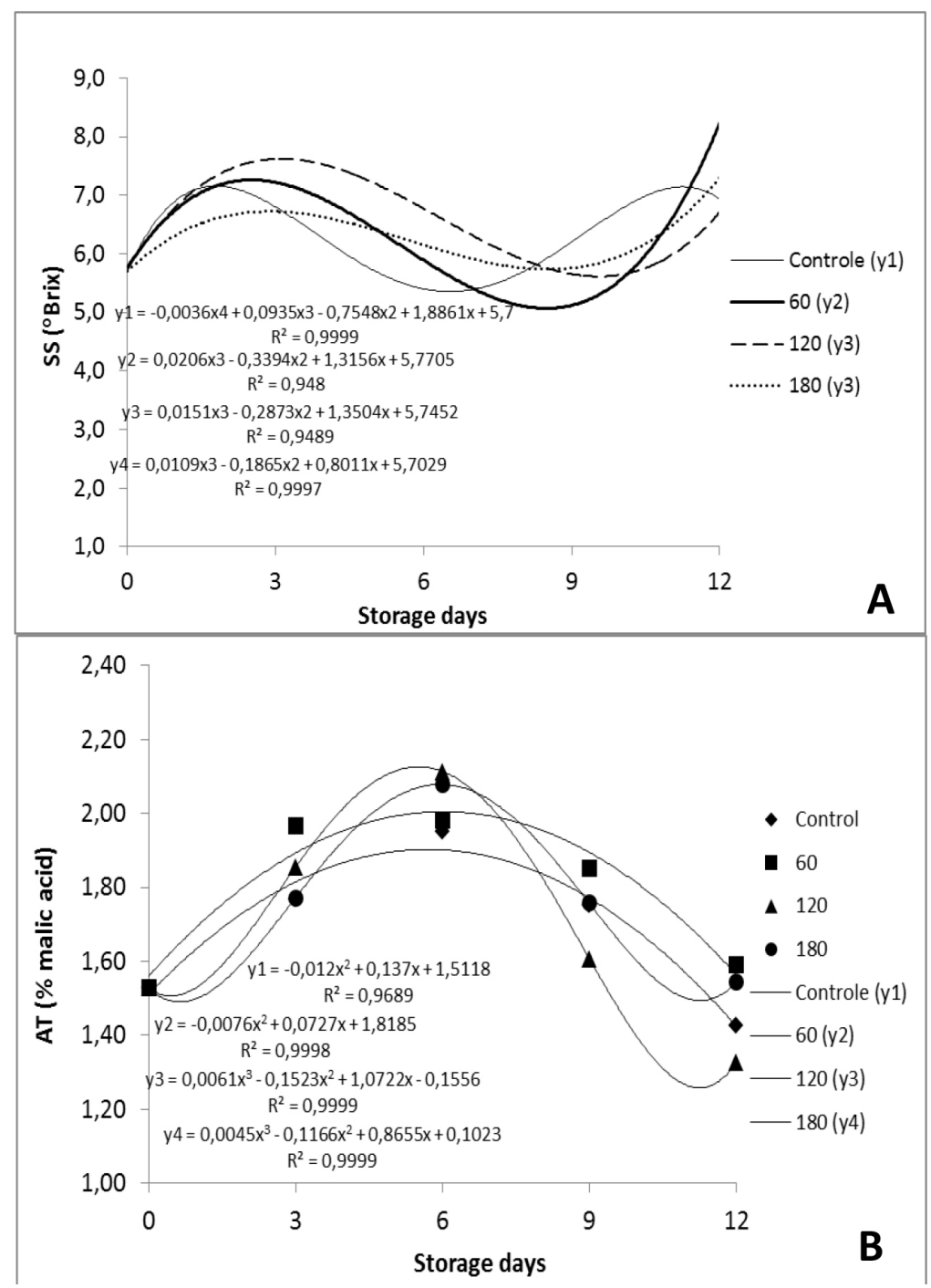

continue... 
continue.

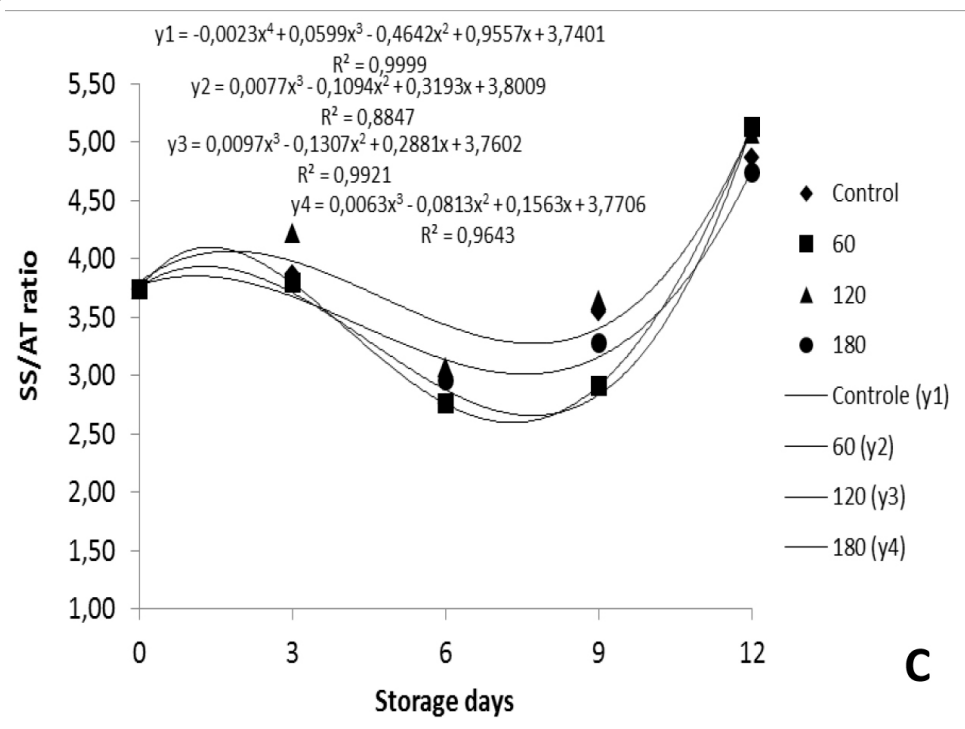

FIGURE 3- Changes on physicochemical attributes of acerola from BRS 236 clone treated with different concentrations of $\mathrm{GA}_{3}$ during 12 days of storage at $10^{\circ} \mathrm{C}$. Soluble Solids (SS; A), Titrable acidity (AT; B) and SS/AT ratio (SS/AT; $\mathbf{C})$.

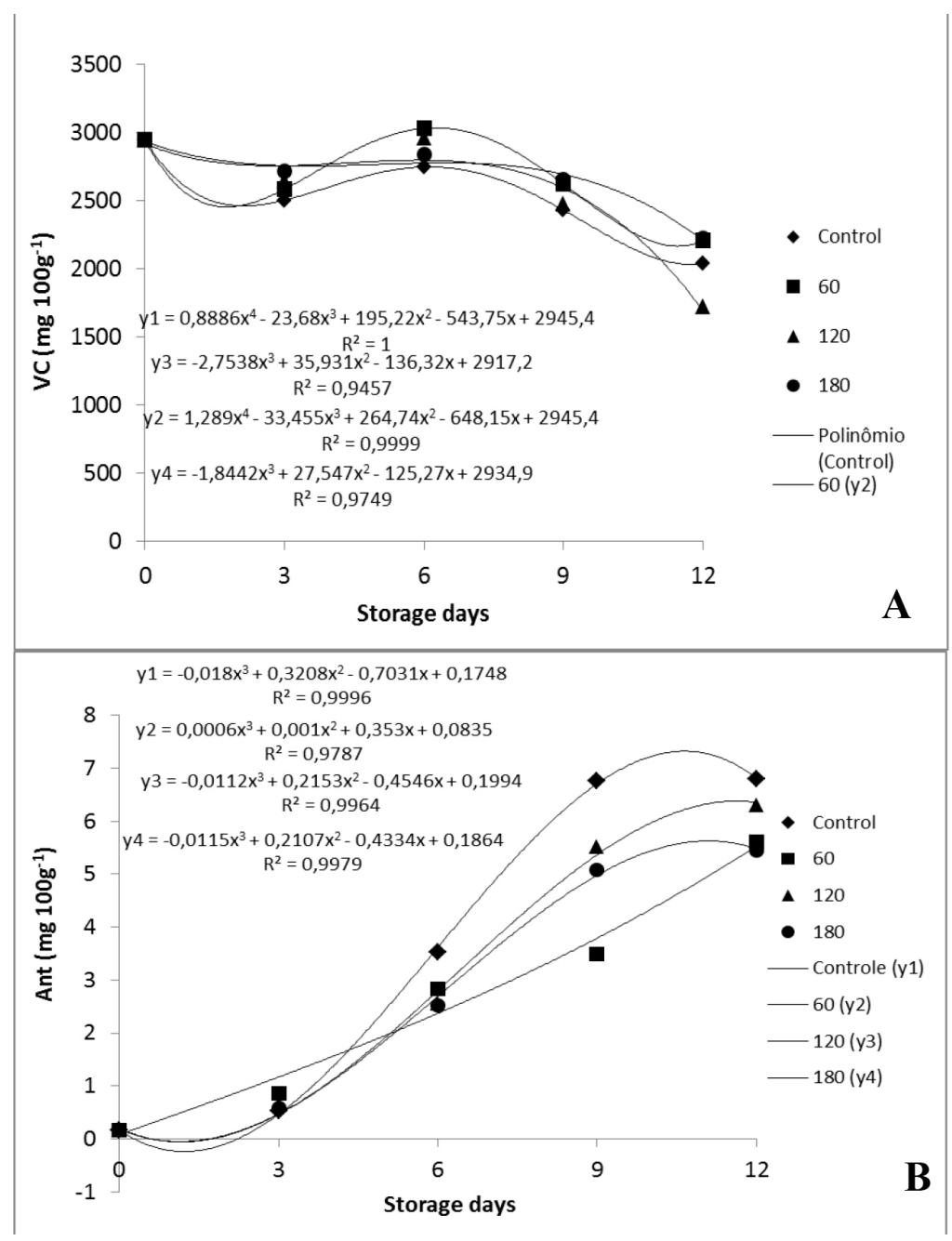

continue... 
continue...

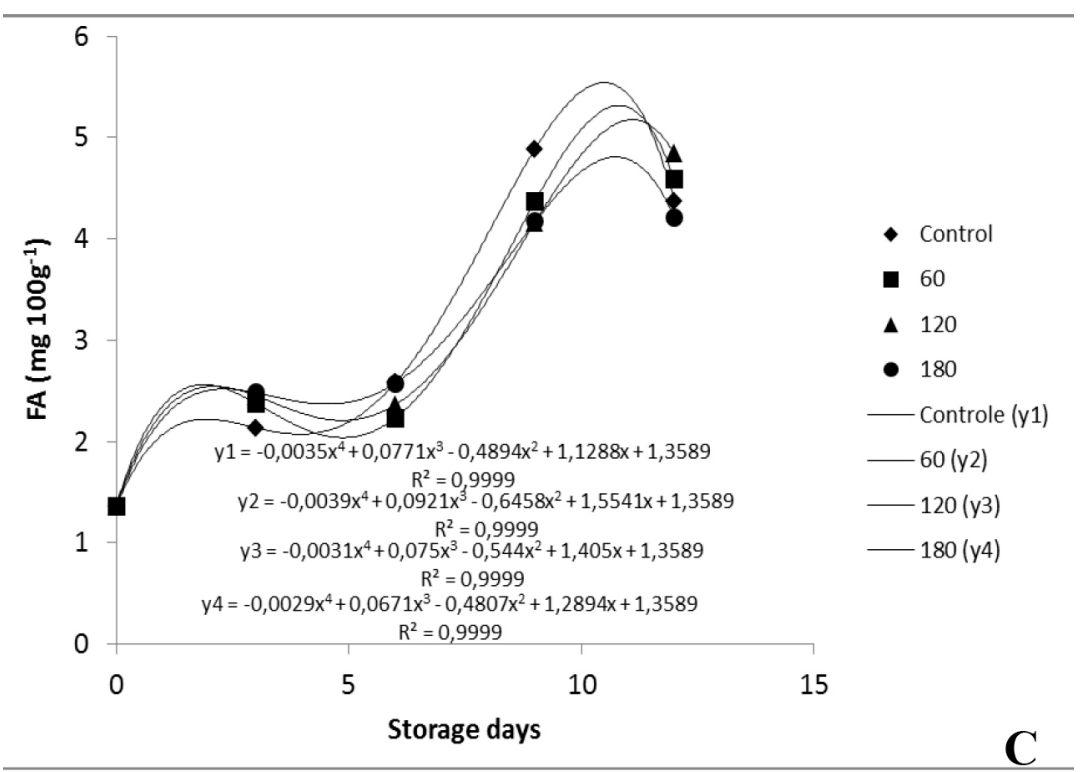

FIGURE 4- Changes on bioactive compounds of acerola from BRS 236 clone treated with different concentrations of $\mathrm{GA}_{3}$ during 12 days of storage at $10{ }^{\circ} \mathrm{C}$. Vitamin $\mathrm{C}(\mathrm{VC} ; \mathbf{A})$, Total Anthocyanins (Ant; B) and Yellow Flavonoids (FA; C).

\section{CONCLUSION}

Acerola treated with $60 \mathrm{mg} \mathrm{L}^{-1}$ presented higher soluble solids content at the end of refrigerated storage. Bioactive compounds such as vitamin $\mathrm{C}$ and yellow flavonoids were not significantly influenced by $\mathrm{GA}_{3}$ at the end of storage. The exogenous application of $120 \mathrm{mg} \mathrm{L}^{-1}$ of $\mathrm{GA}_{3}$ was recommended because resulted in greater red color retention and anthocyanin content in acerola from clone BRS 236 for 12 days of storage at $10^{\circ} \mathrm{C}$.

\section{ACKNOWLEDGEMNT}

The authors would like to thank CNPq, Embrapa Agroindústria Tropical and INCT-Frutos Tropicais.

\section{REFERENCES}

ANTUNES, A.M.; VALMÓRBIDA, J.; ONO, E.O.; RODRIGUES, J.D. Uso de reguladores vegetais na conservação refrigerada de acerolas (Malpighia glabra L.). Ciência e Agrotecnologia, Lavras, v.30, n.6, p.1241-1245, 2006.
AQUINO, A.C.M.S.; MÉS, R.S.; CASTRO, A.A. Estabilidade de ácido ascórbico, carotenóides e antocianinas de frutos de acerola congelados por métodos criogênicos. Brazilian Journal of Food Technology, Campinas, v.14, n.2, p.154-163, 2011.

AOAC - Association of Official Analytical Chemists. Official methods of analysis of the association of official analytical chemists. $18^{\text {th }}$ ed. Maryland, 2005.

CHITARRA, M.I.F.; CHITARRA, A.B. Pós-colheita de frutas e hortaliças: fisiologia e manuseio. 2. ed. Lavras: UFLA, 2005. 785p.

EROGUL, D.; SEM, F. Effects of gibberellic acid treatments on fruit thinning and fruit quality in Japanese plum (Prunus salicina Lindl.). Scientia Horticulturae, Amsterdam, v.186, p.137-142. 2015.

FRANCIS, F.J. Analysis of anthocyanins. In: MARKAKIS, P. (Ed.). Anthocyanins as food colors. New York: Academic Press, 1982. p.181-207.

HUANG, H.; JING, Y. Effect of plant growth regulators on banana fruit and broccoli during storage. Scientia Horticulturae, Amsterdam, v.145, p.62-67, 2012. 
KRISHNA, H.; DAS, B.; ATTRI, B.L.; KUMAR, A.; AHMED, N. Interaction between different pre and postharvest treatment on shelf life extension of Oregon Spur apple. Fruits, Paris, v.67, p.31-40, 2012.

MARZOUK, H.A.; KASSEM, H.A. Improving yield, quality, and shelf life of Thompson seedless grapevine by preharvest foliar applications. Scientia Horticulturae, Amsterdam, v.130, n.2, p.425-430, 2011.

MATSUURA, F.C.A.U.; CARDOSO, R.L.; FOLEGATTI, M.I.S.; OLIVEIRA, J.R.P.; OLIVEIRA, J.A.B.; SANTOS, D.B. Avaliações físico-químicas em frutos de diferentes genótipos de acerola (Malpighia punicifolia D.C.). Revista Brasileira Fruticultura, Jaboticabal, v.23, n.3, p.602-606, 2001.

MILLER, N.J.; RICE-EVANS, C.A. The relative contributions of ascorbic acid and phenolic antioxidants to the total antioxidants to the activity of orange and apple fruit juices and black currant drink. Food Chemistry, Oxford, v.60, p.331-337, 1997.

NOR, S.S.; RAZIFAH, M.R.; MAMAT, A.S.; ADZEMI, M.A. Application of gibberellic acid $\left(\mathrm{GA}_{3}\right)$ in stem cutting of dragon fruit (Hylocereus Polyrhizus): effects on fruit quality and yield at harvest. Journal of Biology, Agriculture and Healthcare, New York, v.4, n.21, p.51-55, 2014.

OLIVEIRA, L.S.O.; MOURA, C.F.H.; BRITO, E.S.; MAMEDE, R.V.S.; MIRANDA, M.R.A. Antioxidant metabolism during fruit development of different acerola (Malpighia emarginata D.C) clones. Journal of Agricultural and Food Chemistry, Davis, v.60, p.7957-7964, 2012.
OZTURK, B.; KUKUKER, E.; KARAMAN, S.; OZKAN, Y. The effects of cold storage and aminoethoxyvinylglycine (AVG) on bioactive compounds of plum fruit (Prunus salicina Lindell cv.'Black Amber'). Postharvest Biology and Technology, Amsterdam, v.72, p.35-41, 2012.

PEREIRA, M.C.T.; CRANE, J.H.; NIETSCHE, S.; MONTAS, W.; SANTOS, M.A. Reguladores de crescimento na frutificação efetiva e qualidade de frutos partenocárpicos de atemóia 'Gefner'. Pesquisa Agropecuária Brasileira, Brasília, DF, v.49, n.4, p.281-289, 2014.

ROSSO, V.V.; MERCADANTE, A.Z. The high ascorbic acid content is the main cause of the low stability of anthocyanin extracts from acerola. Food Chemistry, Oxford, v.103, p.935-943, 2007.

SOUZA, K.O; MOURA, C.F.H.; BRITO, E.S.; MIRANDA, M.R.A. Antioxidant compounds and total antioxidant activity in fruits of acerola from cv.Flor Branca, Florida Sweet and BRS 366. Revista Brasileira de Fruticultura, Jaboticabal, v.36, n.2, p.294-304, 2014.

STROHECKER, R.; HENNING, H.M. Analisis de vitaminas: métodos comprobados. Madrid: Paz Montalvo, 1967. 428p.

YILDIZ, K.; OZTURK, B.; OSKAN, Y. Effects of aminoethoxyvinylglycine (AVG) on preharvest fruit drop, fruit maturity, and quality of 'Red Chief' apple. Scientia Horticulturae, Amsterdam, v.144, p.121-124, 2012. 